\title{
JE LI BLOCKCHAIN TEHNOLOGIJA BUDUĆNOST DIGITALIZACIJE ZEMLJIŠNIH KNJIGA?
}

Josip Dešić, mag. iur.*

Izv. prof. dr. sc. Kristijan Lenac**
UDK: $349.418: 004.3 / .4004 .738 .5: 34$

https://doi.org/10.30925/zpfsr.41.2.9

Ur.: 26. svibnja 2020.

Pr.: 21. lipnja 2020.

Pregledni rad

\section{Sažetak}

U radu se daje prikaz osnovnih značajki blockchain tehnologije $i$ analizira mogućnost njezine primjene u radu zemljišnih registara. Razmatra se kako blockchain može unaprijediti sigurnost $i$ transparentnost registra nekretnina, osigurati integritet podataka, ubrzati i olakšati prijenos prava na nekretninama i postupak upisa. Navode se primjeri Estonije, koja je najdalje odmakla u primjeni blockchain tehnologije u javnoj upravi i uspostavila digitalno društvo, kao i primjer Švedske, u kojoj je 2018. dovršena treća etapa pilot projekta o primjeni blockchain tehnologije u radu zemljišnoga registra. Navode se i primjeri Brazila, Hondurasa, Gruzije i Dubaija. Zaključno se razmatra opravdanost uvođenja blockchain tehnologije u hrvatski zemljišnoknjižni sustav.

Ključne riječi: digitalizacija zemljišnih knjiga; blockchain tehnologija; pametni ugovori.

\section{UVOD}

Zemljišni registri jedni su od najvažnijih javnih registara. Iz zemljišnih registara vidljivi su pravni status nekretnina, narav nekretnina, nositelji prava na nekretninama, ograničenja prava vlasništva i drugi podatci relevantni za pravni promet nekretnina. Uređeni zemljišni registri iznimno su važni za upravljanje nekretninama, prostorno planiranje i zaštitu okoliša. Iako se zemljišni registri i njihovo pravno uređenje razlikuju od države do države, njihov je cilj isti, omogućiti siguran pravni promet nekretninama. ${ }^{1}$

U modernizaciji zemljišnih registara veliku ulogu imaju suvremene tehnologije. Priliku za unaprjeđenje svoga registra nekretnina mnogi vide u blockchainu, decentraliziranoj digitalnoj knjizi, mjestu za pohranu zapisa, koju pokreće mreža računala, od kojih svako računalo sadrži stalno ažuriranu kopiju cijelog blockchaina.

* Josip Dešić, mag. iur., asistent, Sveučilište u Rijeci, Pravni fakultet; jdesic@pravri.hr.

** Dr. sc. Kristijan Lenac, izvanredni profesor, Sveučilište u Rijeci, Tehnički fakultet; kristijan. lenac@riteh.hr.

1 Benjamin Verheye, „Real estate publicity in a blockchain world: a critical assessment“, European property law journal 6, br. 3 (2017): 441-477. 
Njegove karakteristike poput decentralizacije, pouzdanosti i sigurnosti otvaraju širok spektar inovativnih mogućnosti. Pored visoke razine sigurnosti i transparentnosti, jedan je od glavnih motiva za uvođenje blockchain tehnologije u rad zemljišnih registara i mogućnost automatizacije procesa kako bi se skratilo vrijeme i smanjio broj radnji potrebnih za upis. U klasičnom sustavu, može proteći i do nekoliko mjeseci od podnošenja prijedloga za upis i upisa promjena u registar, međutim primjenom blockchaina, cjelokupni se postupak upisa može pojednostavniti i time skratiti vrijeme i smanjiti troškove upisa. ${ }^{2}$

Iako su i ranije neke države informatizirale svoje zemljišne registre, ta je informatizacija obuhvaćala prijenos ručno vođenih podataka u digitalni oblik, ali ne i elektroničku obradu digitalnih informacija. Tek su posljednja dva desetljeća dovela do provedbe ideje o elektroničkom prijenosu prava na nekretninama prema kojoj se prijedlog za upis elektronički obrađuje od etape podnošenja prijedloga, pa čak i sklapanja ugovora, do etape konačnog upisa. Ponajprije valja istaknuti primjere Estonije i Švedske, koje su do sada postigle najbolje rezultate u digitalizaciji i elektroničkoj obradi podataka u zemljišnim registrima (o čemu detaljnije u nastavku rada). ${ }^{3}$

Sve veći broj država diljem svijeta razmatra mogućnost uvođenja blockchain tehnologije u rad registra nekretnina. S jedne strane, postojeći i dobro funkcionirajući zemljišni registri testiraju blockchain tehnologiju kako bi postali učinkovitiji, sigurniji, pristupačniji i transparentniji (npr. Estonija, Švedska), dok se s druge, blockchain tehnologija primjenjuje kako bi se tek stvorio zemljišni registar u zemljama u kojima on danas ne postoji, ili ako postoji, funkcionira na lošoj razini (npr. Gana). ${ }^{4}$

\section{BLOCKCHAIN TEHNOLOGIJA I NJEZINE TEMELJNE ZNA $\breve{C} A J K E$}

Blockchain je distribuirana elektronička knjiga zapisa koja ne zahtijeva centralno mjerodavno tijelo da bi jamčila vjerodostojnost pohranjenih podataka. Takva se tehnologija počela koristiti s bitcoin kriptovalutom kako bi omogućila prijenos digitalne bitcoin valute bez potrebe za pouzdanim posrednikom. Međutim, blockchain tehnologija ubrzo je nadrasla bitcoin te je proširila svoju primjenu na mnoga druga područja (bankarstvo, osiguranje, intelektualno vlasništvo, elektroničko glasovanje, zdravstvo, računovodstvo, e-uprava, zemljišni registri, promet robe itd.). ${ }^{5}$

Ideja je blockchaina jednostavna: izbjeći potrebu za posrednikom korištenjem distribuirane knjige zapisa s čijim se sadržajem svi slažu. Umjesto povjerenja da će neko mjerodavno tijelo ili posrednik jamčiti autentičnost i sigurnost sadržaja, povjerenje se prebacuje na programski kod. No, iako je ideja jednostavna, njezina je implementacija dosta složena. Blockchain održava i pokreće mreža računala koji se

2 Verheye, Real estate publicity in a blockchain world.

3 Tako i Haim Sandberg, „Real estate e-conveyancing: vision and risks“, Information \& communications technology law 19, br. 2 (2010): 101-114.

4 Verheye, Real estate publicity in a blockchain world.

5 Laurence Leloup, Blockchain - La revolution de la confiance (Paris: Eyrolles, 2018.), 129. 
nazivaju čvorovi (engl. nodes), a svako računalo sadrži istovjetnu kopiju cijele baze podataka tako da nema jedinstvene točke kvara (engl. single point of failure). Čvorovi koriste decentralizirani peer-to-peer (P2P) model komunikacije u kojemu čvorovi međusobno komuniciraju s ostalim čvorovima u mreži. Čvorovi su uvijek spremni prihvaćati zahtjeve od ostalih čvorova ili korisnika iste blockchain mreže. ${ }^{6}$

Svi podatci koji se šalju na pohranu u blockchain mrežu kodirani su i digitalno potpisani privatnim ključem pošiljatelja. Čvor koji primi zahtjev provjerava potpis i valjanost podataka te, ako je sve u redu, grupira te podatke s drugim zahtjevima u novi blok podataka. Novi se blok potom slijedno veže na prethodni blok s pomoću kriptografskih tehnika te tako nastaju lanci blokova koji predstavljaju kontinuirano proširivu knjigu zapisa kroz vrijeme. Jednom kada su podatci zapisani i prihvate ih čvorovi u mreži, promjene i brisanja više nisu moguća što blockchain čini neizmjenjivim i trajnim. ${ }^{?}$

Problem koji se uspio riješiti pri uvođenju bitcoin kriptovalute je da je navedeno ostvarivo čak i ako je u blockchain mreži dio čvorova maliciozan i ne prati pravila. Uveden je Proof-of-Work protokol kojim se postiže konsenzus među svim čvorovima u mreži koji je sljedeći validan blok koji će se dodati u lanac. ${ }^{8}$ Kako tekst ovoga rada ne bi bio previše opsežan opis Proof-of-Work protokola, kao i drugih inačica protokola za postizanje konsenzusa koje su kasnije predložene, neće se prikazivati.

Ono što je važno znati je da postizanjem konsenzusa među većinom poštenih čvorova znači da se svi slažu oko sadržaja i stanja baze. Informacije pohranjene u blokovima otporne su na zloupotrebe, čak i onih koji pohranjuju i obrađuju te informacije. To pak znači da prijevare nisu moguće i da više nema potrebe za nekom pouzdanom strankom u koju treba imati povjerenje. Jednom kad se sva računala u sustavu suglase oko informacije u lancu, podatke više nije moguće mijenjati, a da to ne registriraju drugi sudionici iste blockchain mreže. ${ }^{9}$ Svaki pokušaj manipulacije podatcima lako se otkriva. Važno je naglasiti da blockchain ne može spriječiti protuzakonitu aktivnost, međutim on je $100 \%$ učinkovit u njezinu otkrivanju. Svi su podatci digitalno potpisani i provjerljivi svim sudionicima blockchain mreže. Sve to stvara visoku razinu povjerenja među korisnicima. ${ }^{10}$

\subsection{Javni i privatni blockchain}

Blockchain mreže mogu biti javne ili privatne ovisno o razini otvorenosti sustava prema sudionicima.

Javni blockchain (knjiga otvorena svima) karakterizira potpuna otvorenost i decentralizacija, svatko može pristupiti transakcijama i svatko može sudjelovati

6 Arvind Narayanan i dr., Bitcoin and cryptocurrency technologies: a comprehensive introduction (Princeton: Princeton University Press, 2016.), 27-38.

7 Narayanan i dr., Bitcoin and cryptocurrency technologies, 27-38

8 Narayanan i dr., Bitcoin and cryptocurrency technologies, 27-38

9 Jacques Vos, Blockchain-based land registry: Panacea, illusion or something in between?, pristup 17. studenog 2019., www.elra.eu/wp-content/uploads/2017/02/10.-Jacques-VosBlockchain-based-Land-Registry.pdf.

10 Vos, Blockchain-based land registry, 1-26. 
u procesu konsenzusa. Javni blockhain po prirodi je potpuno decentraliziran te ne postoji centralni autoritet ili pouzdana treća strana koja ga nadzire. Programski kod blockchaina i pravila ukodirana u njemu otvoreni su i transparentni. Primjeri javnih blockchaina na otvorenim peer-to-peer mrežama su Ethereum i Bitcoin. ${ }^{11}$

Privatni blockchain je i dalje peer-to-peer mreža gdje svaki čvor sadrži usklađenu istovjetnu kopiju baze koja se ne može mijenjati. Međutim, privatni blockchaini imaju jedinstveno odgovorno tijelo, administratora, koje upravlja mrežom i odlučuje koji će podatci biti zapisani u blockchain mreži, što je zapravo suprotno temeljnom načelu blockchaina. Mreža se sastoji od jednog ili više čvorova koje izvršava administrator i ostali sudionici koji su dobili pravo na to od administratora. Svi sudionici moraju vjerovati administratoru. Zbog toga se model privatnoga blockchaina ne razlikuje mnogo od distribuirane baze podataka u oblaku. ${ }^{12}$

Kompleksni protokoli za postizanje konsenzusa više nisu potrebni da bi se postigao konsenzus oko transakcija koje će biti dodane u blok. To čini privatne blockchain mreže učinkovitijima i bržima što je važno u nekim primjenama. Kod privatnog blockchaina u pravilu je broj čvorova mreže manji, pravila je ovjere lakše prilagoditi i sustav je fleksibilniji. Primjeri projekata koji pružaju programsku podršku za privatne blockchain mreže su Hyperledger Fabric ${ }^{13}$ i Multichain. ${ }^{14}$ Kada grupa vlasnika zajednički administrira privatnu blockchain mrežu, ona se još naziva i konzorcijska ili federirana blockchain mreža. ${ }^{15}$

\section{PAMETNI UGOVORI}

Pametni su ugovori računalni protokoli namijenjeni digitalnom izvršenju ugovora. ${ }^{16} \mathrm{U}$ blockchainu pametni ugovori su računalni programi koji automatski izvršavaju transakcije na blockchainu, odnosno klauzule ugovora, kada se dogodi neki zadani događaj ili ispune određeni uvjeti. Izvršavanje je automatsko, bez potrebe za ljudskom intervencijom ili trećom stranom..$^{17}$ Događaj na koje pametni ugovor reagira može biti unutar same blockchain mreže, primjerice pojavljivanje transakcije određenih svojstava ili može ovisiti o vanjskim pružateljima usluga (engl. oracles) koji analiziraju podatke vanjskog svijeta i pohranjuju ih u blockchain. Pametni ugovori omogućavaju izravno nadziranje i izvršavanje složenih sporazuma među strankama bez potrebe za ljudskom intervencijom. ${ }^{18}$

11 Laurence Leloup, Blockchain - La revolution de la confiance (Paris: Eyrolles, 2018.), 29. et seq.

12 Leloup, Blockchain - La revolution de la confiance, 93 et seq.

13 Detaljnije o projektu Hyperledger Fabric v. na https://www.hyperledger.org/projects/fabric, pristup 20. travnja 2020.

14 Detaljnije o projektu Multichain enterprise blockchain v. na https://www.multichain.com/, pristup 20. travnja 2020.

15 Vos, Blockchain-based land registry, 15-17.

16 Nick Szabo, "Formalizing and securing relationships on public networks," First Monday 2, br. 9 (1997), https://doi.org/10.5210/fm.v2i9.548.

17 Vitalik Buterin, „A Next Generation Smart Contract \& Decentralized Application Platform“, Ethereum White Paper (2015), pristup 20. travnja 2020., dostupno na https://github.com/ ethereum/wiki/wiki/White-Paper.

18 Buterin, A Next Generation Smart Contract \& Decentralized Application Platform. 
Pametni su ugovori jedna od mogućih nadogradnji na koncept blockchaina, gdje se kao vrsta podataka, u blockchain upisuje programski kod. Oni, u biti, nisu ugovori, nego način izvršenja ugovora. Vrlo je malo propisa o pametnim ugovorima, međutim, to ne znači da se postojeće ugovorno pravo i opća načela prava ne mogu primijeniti i na njih ili da su u potpunosti neuređeni. ${ }^{19}$

\section{BLOCKCHAIN I ZEMLJIŠNI REGISTRI}

Među prednostima blockchain tehnologije u radu zemljišnih registara navode se: povećana učinkovitost obrade transakcija i smanjenje troškova, smanjenje pogrešaka tijekom procesa upisa, sprječavanje prijevara, dodatne razine sigurnosti, transparentnost $\mathrm{i}$ integritet podataka te niža razina ranjivosti na prirodne nepogode ili nepogode prouzročene ljudskim faktorom. ${ }^{20}$ Blockchain može uz osiguranje transparentnost $\mathrm{i}$ integriteta podataka putem, tzv. pametnih ugovora ubrzati transakciju nekretninom. Međutim, ustrojstvo zemljišnih registara u različitim pravnim sustavima nije jednako pa će blockchain tehnologija u svakome od njih imati različitu ulogu. Uvođenjem blockchaina u zemljišne registre nemoguće je odgovoriti na svu problematiku s kojom se pojedini registarski sustavi suočavaju, npr. što učiniti kada nekretninu otuđi osoba koja nije vlasnik, ako je pravni posao koji je temelj za stjecanje prava vlasništva nekretnine ništetan ili pobojan i sl., pa će u tim će slučajevima odluku morati donijeti sud u parničnom ili izvanparničnom postupku. ${ }^{21}$

Prednost blockchaina, kao digitalnog registra, je i ta što se digitalnom tehnologijom, razlika između sustava realnih i sustava personalnih folija može lako prevladati. Pri uspostavi digitalnoga registra nije nimalo teško omogućiti da se rezultati pretraživanja rangiraju i prema samim nekretninama (realne folije) ili pak po titularima stvarnih prava (personalne folije). ${ }^{22}$ Transakcija u blockchainu, može biti bilo koji predmet: bitcoin transakcije predstavljaju euro, dolare ili druge kripto valute, dok je predmet transakcije s nekretninom pojedinačna nekretnina u koju su uključena i prava na njoj. Ove predmete u blockchainu možemo vizualizirati kao digitalni paket koji sadrži informacije koje su kodirane u cjelini i koje se nakon toga dodaju u pojedini blok u blockchainu. Pretraživanje takve baze prema osobama prikazat će sve nekretnine na kojima određena osoba polaže pravo vlasništva ili neko drugo pravo, dok će pretraga prema određenoj nekretnini pokazati tko je njezin vlasnik, odnosno nositelj nekog prava na njoj. ${ }^{23}$

Transakcije u blockchainu mogu uključivati sve vrste informacija, uključujući geografske granice ili brojeve čestica i identitet vlasnika (pisani opis svake parcele,

19 Laurent Leloup, Blockchain - La revolution de la confiance, 79. et seq.; Marcelo Corrales, Mark Fenwick i Helena Haapio, Legal Tech, Smart Contracts and Blockchain (Singapore: Springer, 2019.), 5.

20 Victoria Lemieux, „Evaluating the Use of Blockchain in Land Transactions: An Archival Science Perspective“, European property law journal 6 br. 3 (2017): 392-440.

21 Benjamin Verheye, Real estate publicity in a blockchain world, European property law journal 6, br. 3 (2017), 474.

22 Verheye, Real estate publicity in a blockchain world, 455.

23 Verheye, Real estate publicity in a blockchain world, 457. 
GPS koordinate graničnih točaka i satelitske snimke, fotografije i sl..). ${ }^{24}$

U primjeni blockchain tehnologije u državnoj upravi i registrima najdalje je odmakla Estonija. Blockchain tehnologiju u sustav zemljišnih registara, uvela je i Švedska, uspješni su projekti u tijeku u Brazilu, Dubai uvodi blockchain u cjelokupni sustav državne uprave, uređujući baze podataka i međusobno ih povezujući. Gruzija i Ukrajina također testiraju blockchain u radu zemljišnih registara, kao i pojedine afričke države (npr. Gana). Stoga će se u daljnjem tekstu rada detaljnije opisati navedeni projekti.

\section{BLOCKCHAIN TEHNOLOGIJA I ZEMLJIŠNI REGISTAR U ESTONIJI}

\subsection{Pravni izvori zemljišnoknjižnog prava}

Postupak vođenja zemljišne knjige, sastav i zemljišnoknjižni postupak regulirani su ponajprije Zakonom o zemljišnim knjigama. Uz njega relevantni su propisi i Opći dio estonskoga građanskog zakonika, Zakon o vlasništvu, Zakon o vlasništvu na stanovima, Zakon o obveznim odnosima, Zakon o katastru zemljišta te zakoni o planiranju i gradnji. Zakon o parničnom postupku utvrđuje opća pravila postupka upisa. Zakon o vlasništvu definira stvarna prava, njihov sadržaj, osnivanje i prestanak. Postupak izmjere i upisa u katastar, uključujući razmjenu podataka između katastra i zemljišnoknjižnog odjela, propisan je Zakonom o katastru zemljišta. Organizacija rada zemljišnoknjižnog odjela i detaljnija pravila za upis u zemljišnu knjigu propisana su Sudskim poslovnikom, koji donosi ministar pravosuđa. ${ }^{25}$

\subsection{Sustav zemljišnih knjiga u Estoniji}

Prava na nekretninama nastaju, mijenjaju se i prestaju upisom u zemljišne knjige. Stvarna prava na nekretninama publiciraju se putem zemljišne knjige i nitko se ne može pozvati na nepoznavanje podataka iz zemljišne knjige. Zemljišna knjiga generira sve podatke o nekretnini iz katastra zemljišta putem informacijskog sustava $\mathrm{i}$ ta dva sustava međusobno su povezana i razmjenjuju podatke. Sva se zemljišta u Estoniji upisuju u zemljišnu knjigu, a cjelokupni zemljišni registar dostupan je online i svi su dijelovi registra valjani u elektroničkom obliku. Estonija je usvojila njemački model zemljišnih knjiga. Zemljišne knjige vode zemljišnoknjižni odjeli okružnih (prvostupanjskih) sudova. ${ }^{26}$

24 Nir Kshetri, Blockchain-Based Property Registries May Help Lift Poor People Out of Poverty, pristup 12. studenog 2019., https://www.govtech.com/computing/Blockchain-Based-PropertyRegistries-May-Help-Lift-Poor-People-Out-of-Poverty.html.

25 Publikacija Centra za registre i informacijske sustave Tehnički opis estonskih zemljišnih knjiga, Kinnistusraamatu tehniline kirjeldus, pristup 12. studenog 2019., https://www.riha.ee/api/v1/ systems/kr/files/bbc8b460-a526-c746-d91c-fc7e63a8a560.

26 Ingmar Vali, Kadri Laud, Loori Paadik, Electronic land register which forcefully eliminates real estate fraud and corruption, Tallinn 2014., pristup 12. prosinca 2019., www.rik.ee/sites/www. rik.ee/files/elfinder/article_files/Electronic\%20land\%20register\%20which \% 20forcefully $\% 20$ 
Zemljišnu knjigu čini: 1.) registar, 2.) zemljišnoknjižni dnevnik i 3.) zemljišnoknjižni spis. ${ }^{27}$ Registarski dio ima naslov i četiri dijela. U prvi se dio upisuju katastarski podatci: identifikacijska oznaka, površina, adresa, područje, namjena zemljišta, u drugi dio informacije o vlasniku, postoji li zajedničko vlasništvo i veličinu udjela suvlasnika (ako je riječ o suvlasništvu), treći dio obuhvaća informacije o teretima i ograničenjima vlasništva, dok četvrti dio obuhvaća informacije o hipotekama. Zemljišnoknjižni spis čine: 1.) preslika registarskog dijela i 2.) dokumentacija priložena uz prijedlog. U zemljišnoknjižni dnevnik (upisnik) upisuje se činjenica da je sudu pristigao prijedlog za upis, datum donošenja odluke o prijedlogu, datum unosa upisa, potpis osobe koja obavlja upis, vrijednost transakcije i državna pristojba. ${ }^{28}$

Estonski zemljišni registar uređen je po sustavu realnih folija te se pretraga putem interneta može izvršiti jedino prema identifikatoru nekretnine. Podatci iz spisa, dnevnika i arhiva, odnosno detaljniji podatci o nekretnini, mogu se dobiti jedino ako osoba dokaže pravni interes ili uz pristanak vlasnika nekretnine. Usluge se naručuju digitalnim putem, putem javnog bilježnika ili sustava e-usluga, za što se plaća naknada. Korisnik se pritom mora identificirati putem osobne iskaznice ili internetskoga bankarstva. ${ }^{29}$

\subsection{Postupak prijenosa prava vlasništva $i$ zemljišnoknjižni postupak u Estoniji}

Javni bilježnici u Estoniji imaju ekskluzivitet kod sastavljanja isprava o prijenosu vlasništva na nekretninama. Tako se ugovor o kupoprodaji nekretnine između prodavatelja i kupca zaključuje u obliku javnobilježničkog akta. Isprava o prijenosu prava vlasništva na nekretnini koju bi sastavile stranke, a potvrdio javni bilježnik ništetna je. Javnobilježnički akt mora obuhvaćati sve relevantne odredbe i uvjete te prava i obveze ugovornih strana. Nadalje, javni bilježnik osigurava da se prijenos vlasništva odvija u skladu sa zakonom, i prije nego izradi akt o prijenosu prava vlasništva obvezan je provjeriti zemljišnoknjižno stanje. ${ }^{30}$ Time se sprječava, tzv. dvostruka prodaja nekretnina.

Pri sastavljanju isprava, javni je bilježnik obvezan štititi interese obje stranke, utvrditi jesu li ispunjene sve pretpostavke za sklapanje ugovora i njegov upis $u$ zemljišne knjige, jesu li stranke sposobne sklopiti ugovor, je li nekretnina opterećena hipotekama ili drugim teretima i sl. Prijenos vlasništva na nekretnini vrši se upisom u zemljišnu knjigu. Prijedlog za upis zemljišnoknjižnom sudu dostavlja se isključivo putem javnog bilježnika koji je sastavio akt o prijenosu prava na nekretnini. Dostava

eliminates $\% 20$ real $\% 20$ estate $\% 20$ fraud $\% 20 \mathrm{a} \% 20 \% 20 \% 20$.pdf.

27 V. § 10. Zakona o zemljišnim knjigama na www.riigiteataja.ee/en/eli/529012015011/consolide, pristup 15. sječnja 2020.

28 Zakon o zemljišnim knjigama, Republika Estonija, § 13-20.

29 Publikacija Centra za registre i informacijske sustave Tehnički opis estonskih zemljišnih knjiga, Kinnistusraamatu tehniline kirjeldus, pristup 12. studenog 2019., https://www.riha.ee/api/v1/ systems/kr/files/bbc8b460-a526-c746-d91c-fc7e63a8a560.

$30 \S 9-13$. Notariaadiseadus (Zakon o javnim bilježnicima) od 6. prosinca 2000., pristup 21. travnja 2020., https://www.riigiteataja.ee/en/eli/ee/511112013002/consolide/current. 
se obavlja putem elektroničkog informacijskog sustava $e$-Notar. Nakon podnošenja prijedloga za upis, u elektroničkom se registru odmah pojavljuje oznaka koja ukazuje na podneseni prijedlog. ${ }^{31}$

U situacijama u kojima u financiranju kupoprodaje sudjeluje banka i ona neposredno komunicira $\mathrm{s}$ javnim bilježnikom radi upisa tereta na nekretnini. Komunikacija javnog bilježnika i zemljišnoknjižnog suda od 2007. odvija se elektronički (putem sustava $e$-Notar). ${ }^{32}$ Komunikacija je potpuno elektronička u oba smjera, tako da javni bilježnik zemljišnoknjižnom sudu dostavlja prijedlog i akte o osnivanju, prijenosu, prestanku prava na nekretninama u obliku elektroničke isprave i povratno dobiva sudsko rješenje u elektroničkom obliku. ${ }^{33}$

Javni bilježnik dužan je utvrditi identitet obje ugovorne strane i odbiti sastaviti akt o prijenosu prava na nekretninama ako utvrdi da jedna od stranaka nema potrebnu poslovnu sposobnost ili sposobnost biti punomoćnikom ili pravnim zastupnikom. Javni bilježnik u Estoniji dužan je objema stranama ugovora pojasniti njegove učinke, čime kao neovisni stručnjak pomaže u sprječavanju nepromišljenih postupaka i povrede prava stranaka kod prometa nekretnina. ${ }^{34}$

Blockchain tehnologija ne može zamijeniti sve funkcije koje javni bilježnik ima u prometu nekretnina, npr. blockchain tehnologija sama po sebi ne omogućuje utvrđivanje je li osoba poslovno sposobna i razumije li sve posljedice i rizike povezane sa sklapanjem pravnoga posla. Stoga je estonsko Ministarstvo pravosuđa, još uvijek mišljenja da nije razumno ukloniti javne bilježnike kao kontrolni mehanizam kod sklapanja pravnih poslova povezanih s nekretninama. ${ }^{35}$

Nakon što su dokumenti potpisani, javni bilježnik dostavlja prijedlog za upis zemljišnoknjižnom odjelu suda. Od 1. lipnja 2007. javni bilježnici dostavljaju zemljišnoknjižnom uredu prijave za upis isključivo putem sustava $e$-Notar. Nakon potpisivanja transakcije, bilježnik prosljeđuje dokumente i prijavu za registraciju putem sloja sigurne razmjene podataka X-Road, u informacijski sustav zemljišnog registra. Vrlo je važan redoslijed zaprimanja prijave za registraciju. Referenti u zemljišnoknjižnim uredima suda započinju obradu zahtjeva. Cijeli je proces digitaliziran i automatiziran. To znači da se u sustav ne unose dodatni podatci iz dokumenata, jer je njih već upisao javni bilježnik, a upis koji je nastao kao rezultat postupka pripremljen je u informacijskom sustavu registra nekretnina. Donesene odluke ili unosi dostupni su na javnom web sučelju zemljišnog registra odmah nakon što ih je verificirao referent. Nakon verifikacije upisa u informacijskom sustavu zemljišnog registra, obavijest o upisu dostavlja se strankama automatski putem e-pošte. Stranke

31 Real estate guide Estonia, pristup 5. studenog 2019., http://www.gencs.eu/uploads/VG_REG_ EE.pdf.

32 Prema Tatjana Josipović i Hano Ernst, „Javni bilježnici i javni registri“, Zbornik Pravnog fakulteta u Zagrebu 59, br. 6 (2009): 1117-1152.

33 Josipović, Ernst, Javni bilježnici i javni registri, 1128.

34 Jelizaveta Rastorgujeva, Real estate transaction using blockchain technology, pristup 11. studenog 2019., https://www.njordlaw.com/njord-estonia-real-estate-transaction-using-blockchain-technology/.

35 Rastorgujeva, Real estate transaction using blockchain technology 
mogu pristupiti odluci putem interneta, a sustav registrira je li obavijest zaprimljena. ${ }^{36}$

Kako bi se pripremio akt, javni bilježnik koristi informacijski sustav $e$-Notar za sve potrebne upite. Izvornik je potpisan na papiru, ali se u zemljišni registar dostavlja elektronička kopija. Svi se procesi registracije odvijaju elektroničkim putem. Zemljišnoknjižni referent pregledava dokumente bez njihovog ispisa. Odluka se donosi elektroničkim putem, a ako stranke imaju elektroničku poštu, sva komunikacija nakon upisa u zemljišne knjige obavlja se i elektroničkim putem. ${ }^{37}$

Prijedlozi za upis rješavaju se redoslijedom podnošenja. Odluku o upisu donose referenti koji su neovisni u svom radu. Referent može proslijediti odluku sucu: ako se primjenjuje pravo druge države, ako referent želi odstupiti od prakse suca koja mu je poznata ili ako je prema mišljenju referenta odredba koja se primjenjuje suprotna Ustavu. $^{38}$

Registarski dijelovi i zemljišnoknjižni dnevnik čuvaju se elektronički. Cjelokupni postupak registracije podržava računalni program za digitalne zemljišne knjige. Mnoge su rutinske aktivnosti poluautomatske, što proces čini učinkovitijim. Tekstovi unosa automatski se sastavljaju iz predložaka. Zbog toga su rokovi postupka smanjeni s tri mjeseca na približno deset dana, a broj tehničkih radnika u zemljišnoknjižnim odjelima smanjen je za oko $20 \%$. Zahvaljujući digitalnoj strukturiranoj razmjeni podataka s drugim osnovnim registrima kao što su Zemljišni katastar, Trgovački registar, Registar stanovništva, javlja se manje pogrješaka i bitno je smanjena papirologija. ${ }^{39}$

Dokumenti koji se dostavljaju zemljišnoknjižnom odjelu elektroničkim putem moraju biti digitalno potpisani. Početkom 2015., zbog zahtjeva sigurnosnoga standarda ISKE, u zemljišnu se knjigu uvodi digitalno potpisivanje, hash chaining i vremensko pečaćenje upisa kako bi se osigurao integritet podataka i spriječilo neovlašteno mijenjanje i uništavanje podataka. ${ }^{40}$

Zemljišna knjiga u potpunosti je elektronički registar, što znači da se podatci pohranjuju i obrađuju isključivo u elektroničkom obliku. U slučaju papirnatih dokumenata koji se ne moraju predati digitalno, izdaju se njihove ovjerene digitalne kopije. Ako elektronički unos nije moguć, zakon dopušta i uporabu knjižice za zamjenu papira, koja se mora digitalizirati što je prije moguće. ${ }^{41}$

Stranke u zemljišnoknjižnom postupku primaju obavijest o odluci, a stjecatelju

36 Vali, Laud, Paadik, Electronic land register which forcefully eliminates real estate fraud and corruption, 3. Pristup 10. kolovoza 2020., https://www.rik.ee/sites/www.rik.ee/files/elfinder/ article_files/Electronic\%20land\%20register\%20which\%20forcefully\%20eliminates $\% 20$ real $\% 20$ estate $\% 20$ fraud $\% 20 \mathrm{a} \% 20 \% 20 \% 20$.pdf

37 Vali, Laud i Paadik, Electronic land register which forcefully eliminates real estate fraud and corruption, 4.

38 Process of registration in Estonia, European Land Registry Association, pristup 11. prosinca 2019. https://www.elra.eu/contact-point-contribution/estonia/process-of-registration-6/

39 Ingmar Vali, Estonian Land Register, 12. ppt. prezentacija, pristup 12. studenog 2019., https:// www.elra.eu/wp-content/uploads/2016/10/Estonian-land-registerIngmar-2011GA.ppt.

40 Vali, Laud i Paadik, Electronic land register which forcefully eliminates real estate fraud and corruption, 12.

41 Vali, Laud i Paadik, Electronic land register which forcefully eliminates real estate fraud and corruption, 4. 
prava vlasništva nakon provedenog upisa omogućuje se uvid u sve podatke i datoteke koje se vode vezano za nekretninu koju je stekao. Javni bilježnik koji je ovjerio ugovor također prima obavijest o upisu. Razmjena podataka među različitim registrima $\mathrm{u}$ državi odvija se putem sigurnoga sloja za razmjenu podataka $X$-Road, koji omogućuje provjeru ispravnosti podataka i činjenica u stvarnom vremenu. Ako se podatci traže putem X-Roada, nema potrebe za dostavljanjem dodatnih dokaza (potvrda i sl.). $X$-Road je pokrenut 2001. kao tehničko i organizacijsko okruženje koje omogućuje digitalnu i sigurnu razmjenu podataka između državnih informacijskih sustava. ${ }^{42}$

Sustav elektroničke obrade predmeta onemogućuje povredu reda prvenstva upisa. Naime, od 1. lipnja 2007. javni su bilježnici obvezni podnijeti sve prijave za registraciju elektroničkim putem, a od 1. lipnja 2011. dodjela predmeta zemljišnoknjižnim referentima je automatska i predmeti se obrađuju isključivo prema redoslijedu zaprimanja. Sve naknadne promjene u nalogu za obradu mogu se pratiti u informacijskom sustavu, a samo voditelj zemljišnoknjižnog odjela može dodijeliti predmet drugom referentu. Time sustav osigurava transparentnost i sprječava zloupotrebe. ${ }^{43}$

Estonskoj zemljišnoj knjizi (svim dokumentima i datotekama) može se pristupiti isključivo putem interneta, za što se plaća naknada. Svatko tko želi pristupiti zemljišnoknjižnoj datoteci mora dokazati pravni interes da to učini. ${ }^{44}$ Jedini koji nisu dužni navesti razlog za pretragu datoteka su vlasnici nekretnina, javni bilježnici, sudovi i druga tijela vlasti. Vlasnici mogu ovlastiti pojedine osobe (npr. buduće kupce) da pretražuju određenu zemljišnoknjižnu dokumentaciju. Dokumenti se mogu pregledavati uz provjeru elektroničkog identiteta (putem osobne iskaznice i koda), nakon čega je moguće točno utvrditi osobu koja je izvršila uvid u (digitalnu) dokumentaciju. ${ }^{45}$

\section{BLOCKCHAIN TEHNOLOGIJA I ZEMLJIŠNI REGISTAR U ŠVEDSKOJ}

U Švedskoj zemljišni registar ne vodi sud, već Lantmäteriet (Uprava za kartografiju, katastar i registraciju vlasništva na nekretninama). Lantmäteriet se sastoji od Službe za katastarske usluge, Geodetskog odjela te Registarskog odjela. Upravo je Registarski odjel taj koji ispituje, donosi odluke i registrira pravo vlasništva i druga prava koja se zatim upisuju u Registar nekretnina. ${ }^{46}$ Švedska je jedna od prvih država u svijetu koja je još 1973. započela s digitalizacijom svoga zemljišnoga registra i od tada se taj sustav neprestano razvija i modernizira. ${ }^{47}$

42 Vali, Laud i Paadik, Electronic land register which forcefully eliminates real estate fraud and corruption, 4-5.

43 Vali, Laud i Paadik, Electronic land register which forcefully eliminates real estate fraud and corruption, 11.

44 Estonski registar nekretnina, pristup 3. studenog 2019., www.rik.ee/en/e-land-register,

45 Estonski registar nekretnina.

46 Detaljnije Lantmäterieta, https://www.lantmateriet.se/, pristup 12. studenog 2019.

47 Ulf Jensen, Real estate in Sweden, Lund University. Pristup 13. travnja 2020. https:// www.eui.eu/Documents/DepartmentsCentres/Law/ResearchTeaching/ResearchThemes/ 
U lipnju 2018. u Švedskoj je dovršena treća etapa pilot projekta Blockchain zemljišnog registra. No, službena uporaba blockchain tehnologije u radu zemljišnog registra u Švedskoj još nije započela, budući da nova tehnološka rješenja zahtijevaju i brojne zakonodavne izmjene, ponajprije u administriranju procesa upisa, forme ugovora o kupoprodaji nekretne, identifikacije sudionika, digitalnih potpisa, e-identifikacije, e-dokaza i sl. ${ }^{48}$

Švedska i danas ima pouzdan sustav registriranja nekretnina, a povjerenje $u$ rad državnih tijela je na visokoj razini. Uvođenjem blockchain platforme švedske vlasti žele u potpunosti automatizirati cijeli postupak prijenosa prava vlasništva na nekretnini kako bi se skratilo vrijeme i smanjio trošak upisa prava na nekretninama. ${ }^{49}$

Prema blockchain rješenju, cijelim procesom transakcije i upisa u zemljišni registar upravljao bi pametni ugovor (engl. smart contract) koji bi automatizirao postupak i učinio ga transparentnim na način da svaki korak bude vidljiv svim sudionicima transakcije. Vrijeme od tri do četiri mjeseca, koliko je bilo potrebno od sastavljanja ugovora do upisa prava vlasništva u registar skratilo bi se na nekoliko dana. Putem automatizacije procesa i pametnih ugovora, koje podržava blockchain tehnologija, osigurala bi se transparentnost registra, integritet podataka o nekretnini i nositeljima stvarnih prava te spriječilo eventualno višestruko otuđenje nekretnina. ${ }^{50}$

Prema sadašnjem, klasičnom sustavu prijedlog za upis u registar dostavlja se Lantmäterietu neposredno u registarskom uredu, poštanskim putem ili digitalno. Kod sklapanja ugovora u pisanom obliku u švedskom sustavu nije potrebna javnobilježnička ovjera potpisa. Prema Zakonu o nekretninama, ugovor o kupoprodaji mora sadržavati podatke o kupcu i prodavatelju, identifikacijske oznake nekretnine, izjavu prodavatelja da prenosi vlasništvo nekretnine na kupca i kupoprodajnu cijenu, suglasnost prodavateljevoga bračnog druga te potpise stranaka. ${ }^{51}$ Vlasništvo na nekretnini stječe se u trenutku potpisa ugovora, a upis u zemljišni registar ima deklaratorni karakter. ${ }^{52}$

Izvornik ugovora o prijenosu potrebno je dostaviti registarskom uredu Lantmäterieta zajedno s prijedlogom za upis (prijavom). Ako kupac ne podnese prijedlog za upis u roku od tri mjeseca od sklapanja ugovora, Lantmäteriet može odrediti novčanu kaznu. Na kraju registracije stranke primaju dopis Lantmäterieta o upisu vlasništva s računom za pristojbu i plaćanje poreza.

Švedski sustav za sklapanje i registraciju pravnih poslova u vezi s nekretninama razlikuje se od estonskoga, jer se temelji na uzajamnom povjerenju između sudionika

EuropeanPrivateLaw/RealPropertyProject/Sweden.PDF.

48 The Land Registry in the blockchain (izvješće o švedskom blockchain projektu), pristup 23. listopada 2019., https://chromaway.com/papers/Blockchain_Landregistry_Report_2017.pdf

49 The Land Registry in the blockchain, 2.

50 The Land Registry in the blockchain, 20.

51 Zakon o nekretninama (Jordabalk 1970: 994), poglavlje 4, § 1, pristup 13. travnja 2020., https://www.riksdagen.se/sv/dokument-lagar/dokument/svensk-forfattningssamling/ jordabalk-1970994_sfs-1970-994.

52 Jensen, Real estate in Sweden, Lund University; Monica Johanson, Land Register in Sweden - Present and Future, pristup 13. travnja 2020., https:/www.fig.net/resources/proceedings/ fig_proceedings/fig_2002/Ts7-12/TS7_12_johansson.pdf. 
transakcije. Transakcije ne zahtijevaju ovjeru potpisa od strane javnog bilježnika. U švedskom sustavu za upis u registar nekretnina dovoljni će biti potpisi dvaju svjedoka na ispravi o stjecanju prava. Prema švedskom Zakonu o nekretninama, stjecatelj mora podnijeti zahtjev za upis u zemljišnu knjigu u roku od tri mjeseca od potpisivanja ugovora, ali upis ima samo deklaratorno značenje jer se vlasništvo na nekretnini, $\mathrm{u}$ pravilu, prenosi sklapanjem kupoprodajnog ugovora. Ugovor o kupoprodaji nekretnine moguće je dostaviti registarskom uredu i poštom. Međutim, nedostatak je švedskoga sustava taj što referent u registarskom uredu nikada ne može biti potpuno siguran $u$ autentičnost dokumenta, budući da za perfektnost ugovora nije potrebna ovjera potpisa stranaka od strane javnog bilježnika. ${ }^{53}$

U Švedskoj kod kupoprodaje nekretnine vrlo često sudjeluju licencirani posrednici (brokeri), odnosno agenti za nekretnine. Posrednik u prometu nekretnina zastupa obje strane istodobno, obvezujući se da će ih obavijestiti o svim pravnim okolnostima važnim za sklapanje ugovora. Švedsko pravo ne propisuje stroge formalne zahtjeve za ugovor o prijenosu vlasništva na nekretnini. Stranke mogu same pripremiti ugovor, ali je korištenje usluge posredovanja vrlo često. Cijene usluga posredovanja iznose od 3 do $5 \%$ vrijednosti nekretnine i uglavnom ju plaća prodavatelj. Zbog tako liberalnog sustava kod sklapanja ugovora i čestoga korištenja gotovih formulara ugovora odvjetnici rijetko sudjeluju u tim transakcijama. ${ }^{54}$

Postupak upisa u zemljišne knjige uređen je Zakonom o nekretninama i Zakonom o formiranju nekretnina iz 1970., Zakonom o zemljišnom registru iz 2000., Zakonom o zemljišnom registru iz 1973., Pravilnik o zemljišnom registru iz 2000. i dr. ${ }^{55}$

Glavni su ciljevi uvođenja blockchain tehnologije u Švedskoj:

- ukloniti potrebu čuvanja fizičkih arhiva za pohranu ugovora i datoteka;

- koncentrirati na jednom mjestu podatke koji su uneseni u zemljišne knjige;

- osigurati bolju sigurnost za korisnike sustava;

- brže i transparentnije transakcije (nije moguće naknadno mijenjati podatke unesene u blockchain, što znači da je svaka promjena fiksirana u bloku koji će biti vidljiv);

- brže primanje više informacija i podataka o transakciji te

- $\quad$ spriječiti višestruko otuđenje nekretnina. ${ }^{56}$

U švedskom pilot projektu zemljišni registar temelji se na privatnom blockchainu, u kojem je Lantmäteriet administrator. Međutim, isto tako je moguće uključiti pet do sedam čvorova koje bi činili registarski odjeli. ${ }^{57}$

U blockchain sustavu svi sudionici u procesu prijenosa prava vlasništva na nekretnini registrirali bi se putem računala i potvrdili svoj identitet. Prodavatelj putem aplikacije poziva posrednika (agenta, brokera), posrednik kupca, a kupac banku putem koje se vrši prijenos novca i koja odobrava kredit, i na taj se način

53 Rastorgujeva, Real estate transaction using blockchain technology.

54 The Land Registry in the blockchain, pristup 23. listopada 2019., https://chromaway.com/ papers/Blockchain_Landregistry_Report_2017.pdf/.

55 Johansson, Land Register in Sweden-Present and Future, pristup 12. studenog 2019., www. fig.net/resources/proceedings/fig_proceedings/fig_2002/Ts7-12/TS7_12_johansson.pdf.

56 The Land Registry in the blockchain, 16.

57 The Land Registry in the blockchain, 16. 
odvija cjelokupna komunikacija sudionika. Kupac može potpisati dokumente o kreditu kao i nalog za plaćanje predujma i kupovnine digitalnim potpisom izravno u aplikaciji. Svaki novi korak u transakciji bit će vidljiv svim sudionicima, a po završetku transakcije vlasništvo se prenosi digitalnim putem. Putem aplikacije vrši se upis hipoteke u zemljišne knjige i može se pratiti svaki korak u transakciji. Vrste koraka i tko ih može učiniti definirani su u pametnom ugovoru na blockchainu. Svi sudionici vide informacije o transakciji i imaju dokaz o svim poduzetim koracima. Svaku promjenu u zemljišnom registru odobrava službenik u Lantmäterietu. Sve strane mogu digitalno pohraniti datoteke i zapise o verifikaciji cijelog lanca događaja, a dokumenti se mogu ispisati u fizičkom obliku. Svaka kopija ima kontrolni kod koji je registriran u blockchainu. Digitalni potpisi osiguravaju visoku razinu sigurnosti. Budući da se digitalni potpisi isporučuju s aplikacijom, rizik od pogrešaka i prijevare se smanjuje. Proces uključuje više kontaktnih točaka i višestruke potpise uključenih strana što povećava povjerenje u sustav. ${ }^{58}$

Krajnji je rezultat siguran proces transakcija nekretnina i hipotekarnih ugovora sa sljedećim značajkama:

1. Svi uključeni sudionici imat će digitalnu datoteku koja sadrži sporazum o prijenosu prava vlasništva na nekretninama (ili npr. ugovor o osnivanju hipoteke) i sve podatke o transakcijskom procesu.

2. Autentičnost postupka, potpisa, datoteka koje sadrže isprave o prijenosu vlasništva, hipotekarni poslovi itd. osigurat će se blockchainom, a cijelim procesom upravljat će pametni ugovor, što će dovesti do automatizacije, odnosno ubrzanja postupka i smanjenja troškova.

3. Jedini je način manipulacije i prijevare poduzimanje nove transakcije (pravnog posla s nekretninom) s ukradenom identifikacijskom ispravom. Međutim, sigurnost ID-rješenja može se poboljšati strožim postupkom identifikacije (biometrijska identifikacija, višestruki potpisi i sl.).

4. Podatci i datoteke koji bi trebali biti javni prema švedskom zakonu bit će javni, a oni koji bi trebali biti povjerljivi ostaju povjerljivi.

5. Trenutni je proces osmišljen kako bi uključio zemljišni odjel, agente za nekretnine, kupce, prodavatelje i banke, koji su uključeni u većinu pravnih poslova s nekretninama u Švedskoj. Proces se može redizajnirati kako bi uključio i druge sudionike, kao što su javni bilježnici, osiguravajuća društva i lokalne javne vlasti. ${ }^{59}$

\section{BLOCKCHAIN TEHNOLOGIJA U ZEMLJIŠNIM REGISTRIMA DRUGIH DRŽAVA}

\section{1. Gruzija}

Gruzija je jedna od prvih država, koja je u travnju 2016., počela s primjenom blockchain tehnologije u radu zemljišnoga registra. Za pokretanje pilot projekta

58 The Land Registry in the blockchain, 4.

59 The Land Registry in the blockchain, 4. 
stvaranja zemljišnog registra koji se temelji na blockchainu angažirala je privatnu IT tvrtku Bitfury. Zemljišni registar u Gruziji vodi Nacionalna agencija za javni registar (NAPR), pod nadzorom Ministarstva pravosuđa. Korupcija i veliki broj sporova u pogledu nekretnina dugo su vremena bili veliki problem u Gruziji, posebno u turističkim područjima duž obale Crnog mora. Stoga je Gruzija sredinom 2000-ih pokrenula reformu i započela s digitalizacijom zemljišnog registra i državne uprave. Uvođenjem blockchain tehnologije u rad zemljišnog registra željelo se vratiti javno povjerenje u nacionalne agencije, povećati transparentnost vlasništva na zemljištu, smanjiti učestalost prijevara kao i postići uštede u vremenu i troškovima upisa ${ }^{60}$

\subsection{Gana}

U mnogim afričkim državama zemljišni registri potječu iz kolonijalnih vremena, a velika većina ruralnoga zemljišta nije upisana u registre. U Gani $80 \%$ vlasnika zemljišta nema svoje pravo vlasništva upisano u registar, a sudovi imaju velike zaostatke u rješavanju zemljišnih sporova ${ }^{61}$ Upravo blockchain tehnologija može pomoći da se svi zemljišni registri urede i javno objave putem interneta. U Gani Komisija Ministarstva zemljišta i prirodnih resursa u suradnji sa startup tvrtkom Bitland provodi pilot projekt mapiranja i uspostave zemljišnog registra koji bi se u potpunosti temeljio na blockchain tehnologiji. ${ }^{62}$ Zemljišni registri u Gani nisu ažurirani, a veliki je problem i korupcija i „dvostruko vlasništvo“ na zemljištu. Uređeni zemljišni registar olakšao bi vlasnicima zemljišta pristup hipotekarnom kreditu što bi potaknulo gospodarske aktivnosti i strane investicije. Cilj je projekta ne samo poboljšati upravljanje zemljištem, već i spriječiti korupciju i manipulacije s nekretninama kao i uspostaviti moderan, provjerljiv i nepromjenjiv zemljišni registar. ${ }^{63}$

\subsection{Brazil}

Brazil je savezna država (federacija) koja nema jedinstveni registarski sustav zemljišta. Podatci u katastru i zemljišnim registrima često nisu usklađeni i za iste nekretnine ponekad se koriste različite oznake. To može stvoriti poteškoće pri identificiranju nekretnina. ${ }^{64}$ Nedostatak integracije i sistematizacije zemljišnih registara otvara vrata mnogim zloupotrebama. Stoga je 2012. Uredbom Državnog odjela za pravosuđe, br. 47/15. utemeljen Sustav elektroničkog registra nekretnina (Sistema de Registro Eletrônico de Imóveis, SREI) ${ }^{65}$ Riječ je o digitalnom alatu čiji je

60 Qiuyun Shang i Allison Pricea, „A blockchain based land titling project in the Republic of Georgia“, Innovations: Technology, Governance, Globalization 12, br. 3-4 (2018): 72-78, https://www.mitpressjournals.org/doi/pdf/10.1162/inov_a_00276.

61 Kevin Mwanza i Henry Wilkins, African startups bet on blockchain to tackle land fraud, Reuters, 16. veljače 2018., pristup 22. travnja 2020., https://www.reuters.com/article/us-africalandrightsblockchain/african-startups-beton-blockchain-to-tackle-land-fraudidUSKCN1G00YK.

62 Više o projektu Bitland v. www.bitland.world/about/, pristup 12. studenog 2019.

63 Benjamin Verheye, „Real estate publicity in a blockchain world: a critical assessment“, European property law journal 6, br. 3 (2017): 441-477.

64 Lemieux, Evaluating the Use of Blockchain in Land Transactions, 403.

$65 \mathrm{O}$ brazilskom sustavu više na https://www.irib.org.br/institucional /presidente/mensagens/28, 
cilj olakšati razmjenu informacija između ureda za registraciju nekretnina, pravosuđa, javne uprave i opće javnosti, i koji omogućava pregledavanje podataka u registru nekretnina te podnošenje zahtjeva za izdavanje dokumenata. Za razmjenu dokumenata i informacija zaduženi su zajednički centri za elektroničke usluge u svakoj od jedinica federacije. Utemeljena je i Nacionalna koordinacija centara za elektroničke usluge registra imovine, trajno tijelo čiji je cilj usvajanje zajedničkih standarda i koordinacija rada međusobno izoliranih zemljišnih ureda. ${ }^{66}$

U travnju 2017. Ured za registraciju nekretnina u državi Rio Grande do Sul, u općinama Pelotas i Morro Redondo najavio je pilot projekt u partnerstvu s blockchain start upom Ubiquity. Cilj je ovog pilot projekta uvođenje paralelne platforme za repliciranje postojeće pravne strukture upisa i prijenosa vlasništva na nekretninama, kako bi se smanjili troškovi, poboljšala točnost, sigurnost i transparentnost zemljišnih registara. Novi registri koji se temelje na blockchain platformi u početku bi se koristili kao sigurnosna kopija u slučaju da se izvornik uništi ili zagubi, dok bi dugoročno u potpunosti zamijenili dosadašnje ,papirnate“ registre. ${ }^{67}$

\subsection{Honduras}

U Hondurasu se pravo vlasništva na nekretninama stječe upisom u zemljišni registar. Godine 2004. u Hondurasu je stupio na snagu novi Zakon o vlasništvu, koji je uspostavio sveobuhvatan pravni okvir i uveo nekoliko institucionalnih reformi, uključujući uspostavljanje novoga nacionalnog sustava upravljanja nekretninama (SINAP - Sistema Nacional de Administracion de la Propriedad) i jedinstvenoga sustava registara (SURE - Sistema Unificado de Registros). Međutim, ti se sustavi nisu pokazali otpornima na manipulacije s podatcima o nekretninama (koje se događaju i unutar državnog aparata i putem cyber napada) te je ubrzo postala upitna vjerodostojnost zemljišnih registara. ${ }^{68}$

Stoga je 2015. Vlada Hondurasa u suradnji s američkim start upom Factom, pokrenula projekt uvođenja blockchain tehnologije u rad zemljišnih registara. Factom je predložio rješenje temeljeno na Bitcoin blockchainu koji bi bio oblikovan za održavanje trajne evidencije s vremenskim oznakama. Pilot je projekt bio pokušaj stvaranja transparentnoga zemljišnog registra, međutim, snažan politički otpor, zaustavio je njegov nastavak. ${ }^{69,70}$

pristup 13. studenog 2019.

66 Brazilski sustav elektroničkoga registra nekretnina; Nir Kshetri, Blockchain-based property registries may help lift poor people out of poverty, pristup 28. listopada 2019., www.govtech. com/computing/Blockchain-Based-Property-Registries-May-Help-Lift-Poor-People-Out-of -Poverty.html.

67 Lemieux, Evaluating the Use of Blockchain in Land Transactions, 404.

68 Lemieux, Evaluating the Use of Blockchain in Land Transactions, 397.

69 Lemieux, Evaluating the Use of Blockchain in Land Transactions, 398.

70 Blockchain projekti zahtijevaju snažno javno-privatno partnerstvo, potpuni redizajn procesa upisa i spremnost na tehnološke promjene. Kombinacija društveno političkih čimbenika s čimbenicima povezanim s tehnologijom, kao što je infrastruktura i tehnološka razvijenost, stvaraju uvjete za uspjeh ili neuspjeh naprednih inicijativa za digitalizaciju, prema Raquel Benbunan-Fich i Arturo Castellanos, Digitalization of Land Records: From Paper to Blockchain, 


\subsection{Dubai}

Odjel za zemljište i nekretnine, vladino (upravno) tijelo koje vodi zemljišni registar u Dubaiju, uveo je blockchain platformu kako bi pojednostavnio sveukupne procese transakcija s nekretninama te povećao operativnu učinkovitost. Blockchain sustav koristi sigurnu bazu podataka koja bilježi sve ugovore koji se odnose na prava na nekretninama, uključujući ugovore o zakupu nekretnina. ${ }^{71}$

Vlasništvo i druga stvarna prava na nekretnini (hipoteke, plodouživanje, musataha (pravo građenja) i dr.) sukladno s čl. 1277. Građanskoga zakonika Ujedinjenih Arapskih Emirata stječu se upisom u registar. ${ }^{72}$ Sva raspolaganja kojima se stječu, prenose, mijenjaju ili prestaju stvarna prava na nekretninama, moraju biti upisana $\mathrm{u}$ registar nekretnina, $\mathrm{u}$ suprotnom ne stvaraju pravne učinke. ${ }^{73}$ Prema Upravnoj rezoluciji Odjela za zemljište i nekretnine br. 134 iz 2013. zahtijeva se i upis dugoročnih ugovora o najmu (s rokom trajanja od 10 do 99 godina). Registar najmova kraćih od 10 godina vodi Regulatorna agencija za nekretnine (RERA), koja je 17. rujna 2019. postala dijelom Odjela za zemljište i nekretnine. ${ }^{74}$

Zemljišni registar interoperabilni je sustav povezan s bazama podataka Električne i vodne uprave (DEWA), telekomunikacijskim sustavom i različitim računima povezanim s nekretninama. ${ }^{75}$ Do 2021 . Dubai namjerava u potpunosti digitalizirati cijelu državnu upravu, u čemu bi veliku ulogu imala blockchain tehnologija. ${ }^{76}$

\section{TREBA LI U HRVATSKI ZEMLJIŠNOKNJIŽNI SUSTAV UVESTI BLOCKCHAIN TEHNOLOGIJU?}

Reforma zemljišnih knjiga i katastra zemljišta u Republici Hrvatskoj započela je donošenjem Zakona o zemljišnim knjigama koji je stupio na snagu 1. siječnja 1997. te su time stvoreni preduvjeti za izgradnju modernoga zemljišnoknjižnog sustava za vođenje podataka o nekretninama u elektroničkom obliku. Od tada do danas reforma zemljišnih knjiga i katastra provodi se $u$ kontinuitetu. ${ }^{77}$

Zemljišne knjige vode se elektronički, u Zajedničkom informacijskom sustavu zemljišnih knjiga i katastra (u daljnjem tekstu: ZIS). Naime, Vlada Republike Hrvatske

pristup 30. listopada 2019., www.researchgate.net/publication/329222337_Digitalization _of Land_Records_From_Paper_to_Blockchain.

71 Odjel za zemljište i nékretnine u Dubaiju, pristup 24. rujna 2019., https://www.dubailand.gov. ae/English/Pages/ Default.aspx.

72 Građanski zakonik Ujedinjenih Arapskih Emirata, https://legaladviceme.com/legislation/126/ uae-federal-law-5-of-1985-on-civil-transactions-law-of-united-arab-emirates, pristup 2. svibnja 2020.

73 Zakon br. 7 iz 2019. o izmjenama i dopunama Zakona br. 7 iz 2006. o registraciji nekretnina u Emiratu Dubai čl. 1., Službeni list Emirata Dubai, br. 461/19.

74 Zakon br. 4 iz 2019. o Regulatornoj agenciji za nekretnine, čl. 10., Službeni list Emirata Dubai, br. $4 / 19$.

75 Odjel za nekretnine u Dubaiju, pristup 2. svibnja 2020., https://dubailand.gov.ae/en/\#/.

76 Projekt Smart Dubai, pristup 2. svibnja 2020., https://www.smartdubai.ae/initiatives/paperless.

77 E-Savjetovanje o Nacrtu prijedloga Zakona o zemljišnim knjigama, pristup 11. studenog 2019., https:/esavjetovanja.gov.hr/Econ/MainScreen?Entity Id=9639. 
je putem Ministarstva pravosuđa i Državne geodetske uprave 2003. pokrenula Nacionalni program sređivanja zemljišnih knjiga i katastra, skraćenog naziva Uređena zemlja, u sklopu kojeg je razvijen Zajednički informacijski sustav zemljišnih knjiga i katastra (ZIS). Uspostavom ZIS-a stvoren je jedinstveni registar katastra i zemljišnih knjiga u kojem su ta dva sustava međusobno povezana i razmjenjuju podatke vezane za nekretnine. ${ }^{78}$

Zajednički informacijski sustav zemljišnih knjiga i katastra (ZIS) uveden je u sve zemljišnoknjižne odjele i katastarske urede te je u punom produkcijskom radu od 21. studenog 2016.. Svrha je toga sustava ubrzavanje procesa registracije nekretnina i u katastarskom i u zemljišnoknjižnom sustavu, podizanje razine pravne sigurnosti u prometu nekretnina, racionalizacija i pojednostavljivanje poslovnih procesa te povećanje brzine i kvalitete pružanja usluga. ${ }^{79}$

Nadalje, unutar ZIS-a je razvijena aplikacija One Stop Shop (OSS) te je od 16. lipnja 2014. moguće ishoditi zemljišnoknjižni izvadak neovisno o mjesnoj nadležnosti suda na bilo kojem zemljišnoknjižnom odjelu u Republici Hrvatskoj. Putem OSS-a, odnosno ZIS-a omogućeno je javnim bilježnicima i odvjetnicima izdavanje zemljišnoknjižnih izvadaka sa snagom javne isprave. Građanima je omogućeno od 1. studenog 2015 putem sustava e-Građani pribaviti vjerodostojan zemljišnoknjižni izvadak bez potrebe odlaska na zemljišnoknjižni odjel općinskog suda. Od 15. ožujka 2017. omogućena je dodatna funkcionalnost ZIS-a, pa tako javni bilježnici i odvjetnici kao ovlašteni korisnici elektroničkim putem mogu podnositi prijedloge za upis u zemljišnu knjigu. ${ }^{80}$

Novim Zakonom o zemljišnim knjigama ${ }^{81}$ koji je stupio na snagu 6. srpnja 2019. zemljišnoknjižni postupci određeni su kao hitni postupci. ${ }^{82}$ Zakonom je uvedena elektronički vođena zbirka isprava i elektronički spis. ${ }^{83}$ Komunikacija između zemljišnoknjižnih sudova i državnog odvjetništva vodit će se isključivo elektroničkim putem. ${ }^{84}$ Podnošenje elektroničkog prijedloga za upis u zemljišnu knjigu, sada je omogućeno i putem sustava e-Građani. ${ }^{85}$ Sve to ukazuje da je jedan od glavnih ciljeva novoga Zakona postupni prelazak na potpuno elektroničko poslovanje. Pojednostavljenim procesom namjerava se uskladiti i veći broj zemljišnoknjižnih i katastarskih podataka, čime bi se povećala pravna sigurnost u postupanju $\mathrm{s}$ nekretninama. ${ }^{86}$

Razvojni proces današnje zemljišne knjige još nije završen, a to ne isključuje niti zemljišni registar koji se temelji na blockchainu. Međutim, temeljni je problem

78 E-Savjetovanje o Nacrtu prijedloga Zakona o zemljišnim knjigama.

79 E-Savjetovanje o Nacrtu prijedloga Zakona o zemljišnim knjigama.

80 Projekt „Razvoj One Stop Shop (OSS) za ZIS aplikaciju u zemljišnoknjižnom sustavu $i$ usklađivanje podataka zemljišnih knjiga“, pristup 14. studenog 2019., https://oss. uredjenazemlja.hr/public/index.jsp.

81 Zakon o zemljišnim knjigama, Narodne novine, br. 63/19. (u daljnjem tekstu ZZK).

82 Čl. 97. st. 2. ZZK-a.

83 Čl. 30. st. 1. i čl. 107. ZZK-a.

84 Čl. 105. st. 6. ZZK-a.

85 Čl. 105. st. 1. ZZK-a.

86 E-Savjetovanje o nacrtu prijedloga Zakona o zemljišnim knjigama. 
hrvatskih zemljišnih knjiga što one često nisu usklađene sa stvarnim stanjem. Stoga bi preduvjet za učinkovitost blockchaina (kao i bilo kojeg rješenja koje automatizira procese) svakako bila precizna geodetska izmjera zemljišta te upis izgrađenih zgrada i stanova te (stvarnih) vlasnika nekretnina u zemljišne knjige. Razlog tomu je što je automatizacija procesa putem pametnih ugovora upitna ako podatci u registrima nisu točni i potpuni kako bi omogućili siguran pravni promet nekretnina. Naime, blockchain tehnologija ne pruža pomoć u pogledu pouzdanosti ili točnosti ulaznih zapisa unesenih u blockchain. Ako su u blockchain uneseni netočni podatci, sve dok se koriste ispravni protokoli, mreža će ih prihvatiti i dodati u blockchain, no tada ćemo dobiti beskoristan sustav netočnih podataka. Stoga je za korisnost blockchaina vrlo važno da su uneseni podatci točni, potpuni i istiniti, jer jedino će tada njegova implementacija dobiti svoju punu svrhu.

Kada govorimo o primjeni blockchain tehnologije, potrebno je mudro promisliti o onome što se njome želi postići i koja bi bila korist od nje. Jedni od razloga za to su svakako automatizacija procesa upisa, smanjenje troškova i „papirologije“, broja radnji, pa čak i sklapanje akata o prijenosu prava na nekretninama u digitalnom obliku, gdje blockchain ima brojne prednosti pred drugim tehnologijama. Sve navedeno, može pridonijeti i osnivanju jedinstvene centralne zemljišne knjige, gdje bi bili pohranjeni svi podatci o nekretninama i nositeljima prava na njima na području Republike Hrvatske.

\section{ZAKLJUČAK}

Blockchain tehnologija razvija se velikom brzinom i teško je predvidjeti sve prednosti i mogućnosti koje bi mogla donijeti u nadolazećem razdoblju. Međutim, već sada se može reći da blockchain, putem pametnih ugovora, može unaprijediti i pojednostavniti postupak prijenosa prava vlasništva na nekretnini, osigurati sigurnost podataka, povećati transparentnost, ubrzati postupak sklapanja ugovora i upisa u zemljišnu knjigu te smanjiti troškove, a što može donijeti većoj likvidnosti tržišta nekretnina.

Blockchain tehnologija je, naime, puno više od baze podataka, ona omogućava potpunu automatizaciju postupka od sklapanja ugovora do upisa u zemljišni registar. Postupak sklapanja ugovora i upisa bitno se skraćuje, s nekoliko mjeseci na nekoliko dana. Međutim, njezina primjena nije dostatna za rješavanje svih zemljišnoknjižnih problema. Podatci moraju biti točni kada se unesu, a zapisi moraju obuhvaćati dostatno informacija kako bi bili mjerodavni za pravni promet nekretnina. Novi tehnološki sustav neće biti u većoj mjeri koristan u zemljama u kojima je teško odrediti stvarnoga vlasnika nekretnine i u kojima stanje u zemljišnim knjigama ne odgovara stvarnom stanju nekretnina. Stoga su potpuni i točni podatci o nekretninama preduvjet za učinkovitu primjenu blockchain sustava.

U nerazvijenim i siromašnim zemljama, gdje ne postoje zemljišni registri blockchain tehnologija može biti ključna u borbi protiv siromaštva i korupcije, može spriječiti neovlaštenu promjenu podataka te omogućiti siguran promet, kvalitetnije upravljanje i ulaganje u nekretnine. U zemljama u kojima zbog korupcije 
vlada veliko nepovjerenje u zemljišne knjige, svojom nepromjenljivom poviješću ulaska, blockchain nudi velik potencijal za povećanje transparentnosti. S druge strane, u razvijenim zemljama, gdje je manji rizik od manipulacije podatcima i zemljišnoknjižnom dokumentacijom blockchain je prilika za automatizaciju cjelokupnoga zemljišnoknjižnog postupka. Time se smanjuju i troškovi postupka upisa, broj pojedinih radnji i nepotrebna birokracija.

Digitalizacija zemljišnih knjiga nesporno je vrlo važna, međutim napredna tehnologija krije i mnoge opasnosti. Naime, velika većina stranaka koja sklapa pravne poslove vezane za nekretnine nema niti najmanje informatičko i pravno znanje, a uzevši u obzir vrijednost nekretnina, jednim potpisom ili „klikom“ "na računalu, stranka bi mogla izgubiti velik dio imovine. Isključivo digitalni sustav sklapanja ugovora i upisa, mogao bi onemogućiti zaštitu stranaka i ugroziti njihova temeljna ljudska prava (pravo na mirno uživanje vlasništva, pravo na dom i sl.). Jedino stručna pomoć javnog bilježnika, odvjetnika ili drugoga pravnog stručnjaka, može zaštititi stranke od sklapanja štetnih ugovora i osigurati primjerenu pravnu zaštitu, stoga smatramo da je opisani estonski model optimalan, jer ljudska komponenta ne bi trebala biti zanemarena u digitalnom društvu.

Je li blockchain tehnologija revolucija ili prolazni trend, ostaje za vidjeti, međutim suvremena je tehnologija često prilika za nove pozitivne promjene i ne bi ju se smjelo ignorirati. No, njezina primjena ne bi trebala biti sama sebi svrhom, već bi valjalo razmotriti u kojim bi administrativnim procesima takva tehnologija mogla bila svrsishodna i u kojoj bi ih mjeri mogla unaprijediti.

\section{LITERATURA}

1. Benbunan-Fich, Raquel i Arturo Castellanos. „Digitalization of Land Records: From Paper to Blockchain". Thirty Ninth International Conference on Information Systems, San Francisco 2018: 1-9. Pristup 30. listopada 2019. https://www.researchgate.net/ publication/329222337_Digitalization_of_Land_Records_From_Paper_to_Blockchain.

2. Buterin, Vitalik. „A Next Generation Smart Contract \& Decentralized Application Platform“. Ethereum White Paper, 3 no 37 (2015). Pristup 15. travnja 2020. https://github. com/ethereum/wiki/wiki/White-Paper.

3. Corrales, Marcelo, Mark Fenwick i Helena Haapio. Legal tech, smart contracts and blockchain. Singapore: Springer, 2019.

4. E-Savjetovanje o Nacrtu prijedloga Zakona o zemljišnim knjigama. Pristup 11. studenog 2019. https://esavjetovanja.gov.hr/Econ/MainScreen?EntityId=9639.

5. Jensen, Ulf. Real estate in Sweden, Lund University. Pristup 13. travnja 2020. https:// www.eui.eu/Documents/DepartmentsCentres/Law/ResearchTeaching/ResearchThemes/ EuropeanPrivateLaw/RealPropertyProject/Sweden.PDF.

6. Johansson, Monica. Land Register in Sweden - Present and Future. FIG XXII International Congress Washington, D.C. USA, April 19-26 2002: 1-10. Pristup 12. studenog 2019. www.fig.net/resources/proceedings/fig_proceedings/fig_2002/Ts7-12/ TS7_12 johansson.pdf.

7. Josipović, Tatjana i Hano Ernst. „Javni bilježnici i javni registri“. Zbornik Pravnog fakulteta u Zagrebu 59, br. 6 (2009): 1117-1152.

8. Kshetri Nir, Blockchain-based property registries may help lift poor people out of poverty, pristup 28. listopada 2019., www.govtech.com/computing/Blockchain-Based-Property- 
Registries-May-Help-Lift-Poor-People-Out-of -Poverty.html.

9. Leloup, Laurence. Blockchain - La revolution de la confiance. Paris: Eyrolles, 2018.

10. Lemieux, Victoria. „Evaluating the Use of Blockchain in Land Transactions: An Archival Science Perspective“. European property law journal 6, br. 3 (2017): 392-440.

11. Lemmen, Christiaan, Jacques Vos i Bert Beentjes. „Ongoing Development of Land Administration Standards, Blockchain in Transaction Management", European property law journal 6, br. 3 (2017): 478-502.

12. Mwanza, Kevin, Henry Wilkins, African startups bet on blockchain to tackle land fraud, Reuters, 16. veljače 2018., Pristup 22. travnja 2020., https://www.reuters.com/ article/us-africalandrights-blockchain/african-startups-beton-blockchain-to-tackle-landfraudidUSKCN1G00YK.

13. Narayanan, Arvind, Joseph Bonneau, Edward Felten, Andrew Miller i Steven Goldfeder. Bitcoin and cryptocurrency technologies: a comprehensive introduction. Princeton: Princeton University Press, 2016.

14. Nogueroles Peiró, Nicolas i Eduardo J. Martinez García. „Blockchain and Land Registration Systems“. European property law journal 6, br. 3 (2017): 296-320.

15. Odjel za zemljište i nekretnine u Dubaiju. Pristup 20. studenog 2019. https://www. dubailand.gov.ae/English/Pages/ Default.aspx.

16. Projekt „Razvoj One Stop Shop (OSS) za ZIS aplikaciju u zemljišnoknjižnom sustavu $i$ usklađivanje podataka zemljišnih knjiga“. Pristup 11. studenog 2019. https://oss. uredjenazemlja.hr/public/index.jsp.

17. Rastorgujeva, Jelizaveta. Real estate transaction using blockchain technology. Pristup 11. studenog 2019. https://www.njordlaw.com/njord-estonia-real-estate-transaction-usingblock-chain-technology/.

18. Sandberg, Haim. „Real estate e-conveyancing: vision and risks“. Information \& communications technology law 19, br. 2 (2010): 101-114.

19. Shang, Qiuyun i Allison Pricea, ,A blockchain based land titling project in the Republic of Georgia“", Innovations: Technology, Governance, Globalization 12, br. 3-4 (2018): 72-78, https://www.mitpressjournals.org/doi/pdf/10.1162/inov_a_00276.

20. The Land Registry in the blockchain. Pristup 23. listopada 2019. https://chromaway.com/ papers/Blockchain_Landregistry_Report_2017.pdf.

21. Vali Ingmar, Kadri Laud, Loori Paadik, Electronic land register which forcefully eliminates real estate fraud and corruption, Tallinn 2014., Centre of Registers and Information Systems, Republic of Estonia, Minstry of Justice. Pristup 12. prosinca 2019., www.rik. ee/sites/www.rik.ee/files/elfinder/article files/Electronic\%20land\%20register\%20which $\%$ 20forcefully $\% 20$ eliminates $\% 20$ real $\% 20$ estate $\% 20$ fraud $\% 20 \mathrm{a} \% 20 \% 20 \% 20$.pdf.

22. Verheye, Benjamin. „Real estate publicity in a blockchain world: a critical assessment“. European property law journal 6, br. 3 (2017): 441-477.

23. Vos, Jacques. Blockchain-based land registry: Panacea, illusion or something in between?. ELRA, 7th Annual Publication: 1-26. Pristup 17. studenog 2019. content/ uploads/2017/02/10.-Jacques-Vos-Blockchain-based-Land-Registry.pdf. 


\author{
Josip Dešić* \\ Kristijan Lenac**
}

Summary

\title{
IS BLOCKCHAIN TECHNOLOGY THE FUTURE OF LAND REGISTRY DIGITALIZATION?
}

The paper gives an overview of the fundamental features of blockchain technology and analyses the possibility of its application in the land registry system. The authors consider whether blockchain technology can improve the security and transparency of the land registry system, ensure data integrity, accelerate and facilitate the transfer of real property rights and registration process, whether blockchain can offer something different from technologies already tested in land registry systems and whether this technological solution can change the way land registers perform their functions. This paper gives an overview of positive trends and results, primarily the example of Estonia, which has gone the farthest in applying blockchain technology in public administration and digital society, as well as the example of Sweden, but also examples of Georgia, Dubai, Honduras, Brazil. Finally, the authors consider the possibility and justification of introducing blockchain technology in the Croatian real estate register.

Keywords: digitalization of land registry; blockchain; smart contract.

\section{Zusammenfassung}

\section{BLOCKCHAIN-TECHNOLOGIE ALS ZUKUNFT DER DIGITALISIERUNG VON GRUNDBÜCHERN?}

Dieser Beitrag analysiert die Grundmerkmale der Blockchain-Technologie und erwägt ihre Anwendung im Rahmen der Grundbuchregister. Dabei werden folgende Fragen aufgeworfen: kann Blockchain mehr Sicherheit und Transparenz der Immobillienregister verschaffen, Datenintegrität sichern, und Übertragung von Rechten auf Immobilien und Eintragungsverfahren erleichtern und beschleunigen? Estland, als Paradebeispiel in Anwendung der Blockchain-Technologie in öffentlicher Verwaltung und im Aufbau digitaler Gesellschaft wird angeführt, sowie Schweden, in dem 2018 die dritte Phase des Pilotprojekts zur Anwendung von Blockchain-

* Josip Dešić, Mag. iur., Assistant, University of Rijeka, Faculty of Law; jdesic@pravri.hr.

** Kristijan Lenac, Ph.D., Associate Professor, University of Rijeka, Faculty of engineering, kristijan.lenac@riteh.hr. 
Technologie im Grundbuchsregister durchgeführt wurde. Weitere Beispiele aus Brasilien, Honduras, Georgien und Dubai werden auch unter die Lupe genommen. Zum Schluss wird erörtert, ob es begründet sei, Blockchain-basiertes Grundbuchssystem in Kroatien einzuführen.

Schlüsselwörter: Digitalisierung von Grundbüchern; Blockchain-Technologie; selbstausführende Verträge (smart contracts).

Riassunto

\section{LA TECNOLOGIA BLOCKCHAIN È IL FUTURO DELLA DIGITALIZZAZIONE DEI LIBRI FONDIARI?}

Nel lavoro si illustrano le caratteristiche essenziali della tecnologia blockchain e si analizza la possibilità del suo utilizzo nei libri fondiari. Si considera il modo in cui il blockchain può favorire la sicurezza e la trasparenza del registro immobiliare, assicurare l'integrità dei dati, accelerare e facilitare il trasferimento dei titoli sugli immobili e la procedura di registrazione. Si indica l'esempio dell'Estonia, la quale è andata più lontano nell'applicazione della tecnologia blockchain nella pubblica amministrazione e ha creato una società digitale, come anche quello della Svezia, dove nel 2018 è terminata la terza fase del progetto pilota nell'applicazione della tecnologia blockchain nel funzionamento dei libri fondiari. Nello stesso modo si riporta l'esperienza del Brasile, dell'Honduras, della Georgia e del Dubai. Infine si valuta l'opportunità dell'introduzione della tecnologia blockchain nel sistema croato dei libri fondiari.

Parole chiave: digitalizzazione dei libri fondiari; tecnologia blockchain; contratti intelligenti. 